\title{
Modern Political Communication and Web 2.0 in Representative Democracies
}

\section{Petros losifidis \& Mark Wheeler}

To cite this article: Petros losifidis \& Mark Wheeler (2018): Modern Political Communication and Web 2.0 in Representative Democracies, Javnost - The Public, DOI: 10.1080/13183222.2018.1418962

To link to this article: https://doi.org/10.1080/13183222.2018.1418962

曲 Published online: 29 Jan 2018.

Submit your article to this journal ๘

Q View related articles $\longleftarrow$

View Crossmark data \lceil 


\title{
MODERN POLITICAL COMMUNICATION AND WEB 2.0 IN REPRESENTATIVE DEMOCRACIES
}

\section{Petros Iosifidis and Mark Wheeler}

\begin{abstract}
During the first two decades of the twenty-first century, the social media has facilitated interactive communications between the political elites and public. In the 2016 UK Referendum, the social media became a vehicle for contested political arguments and post-truth positions defined the Remain and Leave camps. For instance, it was claimed that the United Kingdom Independence Party former leader Nigel Farage's anti-migrant tweets influenced many voters. In the 2016 US Presidential election, the victorious celebrity property tycoon Donald Trump maintained a controversial online presence. He posted tweets about his campaign and engaged in a blatantly hateful online discourse aimed at his political opponents. Therefore, does such a usage of the social media aid democratic representation or contribute to a greater destabilisation of modern politics?
\end{abstract}

KEYWORDS social media; hybrid; social movement; anti-establishment; irrational discourse

\section{Introduction}

During first two decades of the twenty-first century, the Internet emerged from being an add-on to the television-based campaigns in western liberal democracies to becoming an essential component within the wider communication of politics. In some respects, the traditional forms of political advertising and alternative forms of elite-public relations have created more plural relations with the electorate through the employment of party websites, candidate blogs and the incorporation of social networks such as Facebook, You Tube and Twitter. However, the social media platforms have been seen to more significantly reconfigure interactive communications between apparently "anti-establishment" capitalist interests and the public to establish new forms of participation.

This article will consider how politicians have employed the social media to affect major changes in recent US Presidential campaigns and the European Union (EU) Referendum. It will employ Chadwick's concept of the "hybrid media system" to consider how the social media has been incorporated into mainstream political communication strategies. "The hybrid media system is built upon interactions among older and new media logics - where logics are defined as technologies, genres norms, behaviours and organisational forms - in the reflexively connected fields of media and politics" (Chadwick 2013, 12).

Such hybridity is reflective of the fragmentation of the media audience; the dissolution of centralised party systems; grassroots political activity; the rise of generic 24/7 news channels and citizen journalism; the global consumption of infotainment and a greater fluidity within political ideologies, presentation and marketing (Chadwick 2013, 12). In this respect, the US Democratic Presidential candidacies of Howard Dean in 2004 
and Barack Obama in 2008/2012 proved to be "game-changers" in shaping the political employment of the social media. While Dean showed how the web could announce his candidacy, Obama demonstrated how to "run an Internet campaign that [used] all the relevant media, most notably television, to blend centralisation, control and hierarchy with decentralisation, devolution, and horizontality" (Chadwick 2013, 209).

Most recently, the Republican Presidential victor Donald Trump utilised the social media to reach out a disaffected electoral base to win the 2016 Presidential election against Democratic nominee Hillary Clinton. The highly controversial Trump, who had established his media capital as a property tycoon and television celebrity on The Apprentice (2004 onwards), developed his online presence through Twitter, where he has regularly posted comments about his campaign, other candidates, political views and the "rigged" mainstream media coverage. Trump was notorious for his negative, aggressive and sometimes blatantly hateful tweets, in which he routinely calls his opponents, political and otherwise, "losers" and "haters." For many, the Trump campaign was accompanied by the rise of "fake news" via close advisor Steve Bannon's online Breitbart News, information provocateurs and "post-truth" politics.

In tandem, the EU Referendum which led to the Brexit decision in 2016 was accompanied by the populist online narrative. The social media echo-chamber tended to reinforce the anti-European rhetoric within the mainstream media led by a chorus of Brexit-led newspapers and Leave campaigners. Across the social media, anti-immigrant sentiment was fuelled by the view that dysfunctional European elite was bent on undermining Britain's economy, sovereignty and self-confidence. This led to the xenophobic falsehoods claiming that a Vote Leave outcome would Canute-like turn back the "waves" of immigrants who were ready to pounce from Eastern Europe and the Syrian refugee crisis.

Therefore, have the modern examples of the deployment of the social media within political campaigns-aided democratic forms of political representation or have they contributed to a greater destabilisation of modern politics? Moreover, have the new communications techniques overcome the perception of a democratic deficit or have they contributed to a greater sense alienation and distrust in the political process?

\section{US Presidential Elections - the Internet from the Periphery to the Centre of Campaign Operations}

Throughout the early Internet campaigns within the 1990s and 2000s, the social media was seen as a supplementary medium to television. Invariably, Presidential candidates continued to plough their resources into traditional spot adverts and the buying up of air-time. However, this attitude changed when the little-known Governor of Vermont Howard Dean ran for the Presidential nomination in the 2004 Democratic Primaries. Dean not only used the Internet for funding drives and campaign communications but to open up the way for a "citizen-initiated" approach (Gibson 2010, 7). In turn, Barack Obama would take significant advantage of the social media while continuing to employ the political communications principles drawn from the television age (Chadwick 2013, 199).

In 2008, a significant change in political campaign management occurred as Obama realised that the social media could facilitate a "shift ... toward a looser 'hybrid' mode of operation that incorporated the network tactics of protest movements" (Gibson 2010, 5). 
The Obama campaign established the MyBo site which after a straightforward registration process offered users with a wide degree of involvement in an online political community. It encouraged recruitment drives and enabled local associations, invariably drawn from youth groups, college students and non-traditional political actors to organise as grassroots activists, thereby working in an inclusive and relational manner (Bang 2009, 132).

Therefore, across the battleground states, Obama's utilisation of social networking technologies enabled his campaign organisation to swell to 1.5 million community organisers. To aid their door-to-door canvassing, volunteers accessed constantly updated databases through field offices and via MyBo concerning information about potential voters' political leanings (Lai Stirland 2008). This blend of volunteering, gumshoe canvassing and information processing became the hallmark of the Obama campaign as it built, tweaked and tinkered "with its technology and organisational infrastructure ... to successfully integrate technology with a revamped model of political organisation that stresses volunteer participation and feedback on a massive scale" (Lai Stirland 2008).

Through these inclusive techniques, Obama remained in constant touch with his core support and attracted online activists. He defined a political image founded on reciprocity to encourage the popular scrutiny of his ideas. Obama's social media campaign represented more than just "Obama as a candidate" but enabled him to galvanise a social movement mobilised by "Obama as a cause" (Heilemann and Halperin 2010, 52). Throughout the 2008 and 2012 campaigns, Obama's approach demonstrated how Internet had reconfigured the nature of political marketing:

What resulted was not only a victory for the Democrats and Obama, but also the legacy of what was widely regarded as one of the most effective Internet marketing plans in history - where social media and technology enabled the individual to activate and participate in a movement. (Chang 2008, 2)

\section{Donald Trump - Voice and Output: Political Outsider, Outrage and Charismatic Authority in 140 Characters}

While in many respects, Obama and Trump were the polar opposites of one another, Trump's 2016 campaign built upon Obama's online presence by re-configuring notions of reciprocity and reaching out to an electoral base via the social media. Further hybridity occurred between Trump's media stardom, his construction of a social movement and his utilisation of charismatic demagoguery across the Internet. Like other twenty-first century political candidates, Trump maintained a presence across social media platforms. He used many obvious techniques (direct address, polling audience, posting pictures with his family and behind the scenes information). However, Trump's most notable online contributions occurred via Twitter, where he posted comments on a daily basis about his right-wing political views, the success of his campaign and the "unfair" coverage he received in the mainstream media.

Trump's Twitter handle itself - @realDonaldTrump - directly communicated the idea that the content he presented was genuine and unfiltered so he could speak to a broader social movement. He used Twitter to point out the alleged fakery of others to position him as an honest, plain-spoken, unfiltered foil, whose brash sincerity and unapologetic vehemence stood as a pillar of his brand. Twitter enabled Trump to provide a public voice 
with an increasingly disaffected public when he claimed he would "drain the swamp" within the Washington beltway.

As an outsider "businessman" Trump rallied against the elites and special interests, while maximising his own personal and financial attributes to build up reciprocal relations with his online audiences who enjoyed his reactionary populism. Consequently, it was Trump the maverick billionaire capitalist, who had never stood for any other political office, that managed to present himself as the "anti-establishment" candidate by blackening his media critics, Republican Party Primary opponents such as Senators Ted Cruz and Marco Rubio, and ultimately the Democratic Presidential nominee - "Crooked" Hilary Clinton. Therefore, through such "authenticity" he established a deep and rooted connection with the rust-belt electorate who felt they had been ignored and betrayed by the political and media establishments.

He used his hybrid media/digital presence to enhance his personal brand, which had been created via the tropes of Reality TV, Gossip Columns and Talk Radio to establish a form of political capital with the American public. Trump provided an expression of celebrity leadership via the interface of social media platforms with his outrageous media performances throughout the primary and election debates, alongside campaign rallies where he rallied his supporters that he would imprison Clinton. He successfully propelled his candidacy through a purposefully controversial social media performance in which he engaged in an outlandish and hateful commentary. In such a manner, he constructed a deliberate and contradictory news agenda, which demonstrated that:

The only thing that's really changed between Trump's other attempts to run for office and now is the advent of social media. And Trump, who has spent his life offending people, knows exactly how to bend it to his will.... The more the TV shows talk about him, the more we all talk about him. If you want to truly comprehend why Trump is so popular, you just have to behold what people are saying in 140 characters. (http://www. vanityfair.com/news/2016/04/how-silicon-valley-created-donald-trump)

An early example of Trump's outrageous Twitter "performance" was evident when he engaged in a sexist and derogatory attack upon the ex-Fox New Presenter and GOP (Grand Old Party) primary debate moderator Megyn Keller. Previously, she had the temerity of being critical of his political grandstanding, so Trump tweeted, and "I refuse to call Megyn Kelly a bimbo, because that would not be politically correct. Instead I will only call her a lightweight reporter!" (http://abcnews.go.com/Politics/history-donald-trumpmegyn-kelly-feud/story?id=36526503).

Throughout the 2016 President campaign, Trump mastered Twitter unlike any other presidential candidate before him by unleashing its power to be a tool of political promotion, distraction, score-settling and attack. In the process, he fulfilled the fantasies of those social media avatars who had predicted a White House candidacy that would replace the expensive conventions of political communication with a campaign, which emphasised the urgent and visceral nature of the social media. As Trump has shown, within online modern political campaigns there has been a recurring focus on an imagery that gives "voice" to the irrational and projects an ego who seeks constant attention:

If we're talking about them, [he is] winning the war for attention. No one knows this better than Trump. Prod the social-media tiger, you get attention: say Mexicans are rapists, make 
fun of the disabled, pick a fight with the Pope, attack women, call the media dumb, and social media shines a big, bright spotlight on Donald. (http://www.vanityfair.com/news/ 2016/04/how-silicon-valley-created-donald-trump)

\section{EU and Brexit: Fake News on the Social Media}

Donald Trump's victory was welcomed by the variety of new, populist right-wing political parties across Europe. These parties have spread a form of populist nationalism which has placed pressure upon the project of the EU which was designed to promote democracy, freedom, peace and economic reconstruction. During her failed bid to become French President, Marine Le Pen, the leader of the National Front political party, promised that she would pull France out of the Euro and hold a "Frexit" referendum on membership of the EU. She told CNN in an interview that Trump's victory is "a sign of hope for those who cannot bear wild globalisation" (http://edition.cnn.com/2016/11/15/politics/marine-lepen-interview-donald-trump/). Similar to Le Pen, like-minded Hungarian Prime Minister Viktor Orbán has heralded Trump's election victory as the end of "liberal non-democracy" (http://www.independent.co.uk/news/world/europe/donald-trump-us-election-win-hunga rian-prime-minister-viktor-orban-end-liberal-non-democracy-a7413236.html).

The biggest upset to the EU project occurred on 23 June 2016 when the British people decided in a referendum to leave the EU by almost 52-48 per cent. The vote for Brexit has been well-documented and several explanations have been put forth, though two factors mattered the most: immigration and sovereignty, both representing a desire for people to take back control of their own lives and the feeling that they are unrepresented by politicians. These ideas signify fear and alienation and represented a retreat back towards nationalism and borders. The media influenced the referendum result as the reporting of immigration particularly in the tabloid press was extremely negative well before the campaign began, with a steady stream of stories about immigrants "sponging" off the welfare state, "bleeding the National Health Service dry and being involved in criminality" (http://www.referendumanalysis.eu/eu-referendum-analysis-2016/section-1-context/under standing-the-role-of-the-mass-media-in-the-eu-referendum/).

But it was not only the mainstream media that played a role in the decision to leave the EU. In fact, the EU referendum can be dubbed as the first "digital referendum" because both the official Leave ('Vote Leave') and Remain ('Britain Stronger in Europe') campaigns utilised key aspects of the successful Obama model developed during the 2008 and 2012 US Presidential Elections. In an effort to identify and then mobilise their respective followers, the two opposite campaigns used big data mining, data analysis, micro-targeting and social media for intelligence gathering purposes to construct detailed and personalised voter profiles.

The Internet and social media were heavily used for getting their messages across the electorate, though the Leave campaign was much more successful at targeting than the Remain campaign eventually resulting in victory (http://www.referendumanalysis.eu/eureferendum-analysis-2016/section-7-social-media/leave-versus-remain-the-digital-battle/). A large-scale social media data analysis demonstrates that not only did Brexit supporters have a more powerful and emotional message, but they were also more effective in the use of social media like Facebook, Twitter and Instagram. A combination of factors, such as the more intuitive and straightforward messaging by the Leave campaign (which is crucial for social media campaigning) and the highly emotionally charged nature of 
messages (which facilitated the viral spread of Leave ideas) led to the activation of a greater number of Leave followers at grassroots level, something that eventually influenced many undecided voters (http://www.referendumanalysis.eu/eu-referendum-analysis-2016/ section-7-social-media/impact-of-social-media-on-the-outcome-of-the-eu-referendum/).

So the EU referendum showed that social media tools can be used to shape the public agenda, form public opinion and drive social change - for better or for worse. In parallel with Trump's sensational victory, the vote for Brexit was secured in what has been dubbed the era of "post-truth politics" largely based on fake news, the misuse of statistics and appeals to emotion rather than policies and facts. In this capacity, hybrid media and online discourses constructed a potent "politics of fear" which impacted on the UK electorate's political thinking. It may yet prove a costly game for the British people and the rest of the EU citizens. One worrying trend in the new world is that stretching the truth can be seen as just part of a game. European leaders are struggling to absorb the impact of Internetspread fake news on balloting around the world as the continent faces a series of elections during 2017 that will reshape its future. Post-truth in politics is one of the drivers of populism and it is one of the threats to democracy.

Most especially, the prominent Leave campaigner, ex-Mayor of London and Conservative Cabinet member Boris Johnson's cavalier attitude to the truth received a significant hearing throughout the news and social media during the EU Referendum Campaign. Jonathan Freedland compared Johnson with Trump by declaring him to be a "post-truth" politician:

Johnson reminded us that he has more in common with Trump than just a lovingly styled, idiosyncratic head of blond hair. ... On BBC Radio 4's Today programme, Johnson reminded listeners how slippery his grasp on the truth has long been.... As with Trump, humour plays a crucial part. ... Too often, radio and TV interviewers want to appear in on the joke, to share in the chuckle... But it's clear why this matters ... (as) ... how can we have a functioning democracy when we cannot agree on the most basic facts? (http://www.theguardian. com/commentisfree/2016/may/13/boris-johnson-donald-trump-post-truth-politician)

By engaging in a race to the bottom, Johnson's unreliable political discourse (along with that of the UK Independence Party - UKIP - former leader Nigel Farage) meant that his arguments concerning the EU debate were distorted around immigration. Therefore, Johnson's wilful irresponsibility (with Michael Gove, Chris Grayling, lan Duncan Smith, John Mann and Frank Field) was a contributory factor to the "ugliness" that surrounded the national conversation about the referendum.

Farage, a right-wing populist and anti-European Parliament politician who had a key role in the Brexit plebiscite, played a nationalist card by depicting hordes of Middle Eastern immigrants ready to land in the UK in campaign posters. His infamous "Breaking Point" poster can be described as a "fake" since it showed a queue of migrants at the Croatia-Slovenia border, trying to get into Britain. Johnson and Gove, leaders of the Vote Leave campaign, also played the immigration card and delivered fake news as one of its posters claimed: "Turkey (population 76 million) is joining the EU" and Penny Mordaunt, a Defence Minister, claimed the Government would not be able to stop Turkish criminals entering the UK or to veto Turkey's EU accession (the latter a downright lie).The ultimate piece of fake news was the claim that leaving would provide a $£ 350 \mathrm{~m}$-a-week bonus for the NHS from the UK's contribution to EU coffers (http://www.independent.co.uk/voices/ michael-gove-boris-johnson-brexit-eurosceptic-press-theresa-may-a7533806.html). 
Anticipating/echoing Trump, another main slogan of the Brexiteers, was "we want our country back." But given that Parliamentary scrutiny for Theresa May's Brexit strategy is strictly limited in the post-Referendum era, the irony is that Brexit is not restoring the sovereignty of the UK Parliament. As for the journalists who forecast long-term severe economic consequences for a post-Brexit UK economy (in particular, fall in the pound and higher inflation), these are criticised by Brexiteers as "unpatriotic" who write "hyped up media reports," quite similar to Trump's "fake news" attack.

\section{Conclusion}

US Presidential candidates initially treated the Internet with circumspection as they remained unconvinced about whether there could be a greater outreach to the electorate. However, as the Internet rapidly expanded, the new communications formats of the social media offered the politicians with greater opportunities to reconfigure their campaign strategies. Obama was to realise the full worth of these campaign strategies in 2008. He employed a hybrid media approach in which he used more traditional forms of image management, along with a communitarian-inspired approach to the social media to affect a political movement. Through Obama's intricate machine of a network of volunteers, he won key states in the Democratic Primaries from the front-runner Senator Hillary Clinton and in the General Election against his opponent Republican Senator John McCain.

Clinton faced another new social media form of political communication when she was pitched against Donald Trump in 2016. Trump had enjoyed national name recognition and bullish reputation since the 1980s thanks to his business empire, which includes real estate, casinos, resorts and golf courses, books, and beauty pageants. In the 2010s, Trump had become a brand and he stridently developed his populist celebrity by questioning the legitimacy of Obama's birth rights to rule as US President. Therefore, he used his celebrity capital as a base to change the parameters of social media campaigning with his negative, aggressive and hateful employment of Twitter which reflect his para-social relationship with the American public. By lashing out at his political opponents and using cruel humour, he positioned himself as the anti-establishment candidate who regularly tweeted his contempt of the political elite to directly speak and activate a disaffected electoral base. In his first year of office, Trump has continued to employ Twitter to denigrate his opponents, to rail against the "fake news" agenda while using the social media to engage within it, and to deflect attention away from his own political failings.

In the UK, the EU Referendum and in particular the Leave Campaign that was masterminded by political leaders Boris Johnson and Michael Gove's precipitous excess in distorting truths, delivering notions of sovereignty and patriotism that veiled a strain of xenophobia, and spreading negative views against immigrants through social media proved effective for mobilising the majority. In its 2016 report, the House of Commons Treasury Select Committee noted that "the public debate is being poorly served by inconsistent, unqualified and, in some cases, misleading claims and counter-claims." It is then hard to argue that the EU Referendum, characterised by falsehoods and fairy tales disseminated by social media, actually benefited the British democratic system.

Trump, along with the Brexiteers, became the ultimate manifestation of "voice" and "output." Here it is contended that virtuous civic duties are being replaced by alternative forms of engagement and participation in which the outcomes may play out to public prejudice. John Keane (2009) maintains that a "Monitory Democracy," in which 
consumer-led representations have become the measurement of accountability. Most especially, the social media contains both opportunities for pluralism and the manifestation of public obedience to re-configured elites who proclaim to represent the dispossessed. Trump's Twitter strategy explicitly enhanced his charismatic authority which, as outlined by Max Weber, rests on the individual's ability to continuously "prove" his legitimacy, determination and strength; when he does so, followers are compelled to "faithfully surrender" to him (Weber [1946] 1998, 78). In tandem, reading the EU Referendum campaign in terms of some of the personalities involved suggests that key figures such as Farage positioned himself as outsider to elite political institutions, thereby aligning himself (like Trump) with the disenfranchised masses, while Johnson's political opportunism and desire for individual political power led to an emotionally charged campaign and eventually incoherent exit strategy.

This means that these types of engagement with social media are highly questionable in preserving political consensus and have exposed the fissures in modern democracies. Therefore, from these examples, a mixed picture has occurred with regard to the usage of online techniques in representative democracies and there are still many questions about whether they actually encourage a greater form of public efficacy. Most observers today concur that especially in regard to social media, modern communication technologies have impacted profoundly on politics and participation. But the problem is that there is still no overarching agreement in terms of how and to what extent this impact takes place, and what significance it has for democratic politics (losifidis and Wheeler 2016). In the cases of Trump's Twitter strategy both in his campaign (and within the early period of his Presidency) and the use of social media by Brexiteers, it is clear that the social media engagement has been highly controversial in relation to democratic deficits and that the usage of online techniques has left open questions as to whether democratic consensus can be achieved.

\section{DISCLOSURE STATEMENT}

No potential conflict of interest was reported by the authors.

\section{REFERENCES}

Bang, Henrik P. 2009. "'Yes We Can': Identity Politics and Project Politics for a Late-Modern World." Urban Research \& Practice 2 (2): 117-137.

Chadwick, Andrew. 2013. The Hybrid Media System: Power and Politics. Oxford: Oxford University Press.

Chang, Victoria. 2008. "Obama and the Power of the Social Media and Technology." Unpublished Paper. Stanford Graduate Business School. August 27. Case Number: M-231.

Gibson, Rachel K. 2010. "Parties, Social Media and the Rise of 'Citizen-Initiated' Campaigning." Paper presented at the American Political Studies Association.

Heilemann, John, and Mark Halperin. 2010. Race of a Lifetime: How Obama Won the White House. New York: Viking Penguin.

House of Commons. 2016. The Economic and Financial Costs and Benefits of the UK's EU Membership. First Report of Session 2016-17. The Treasury Committee. HC122. 
Iosifidis, Petros, and Mark Wheeler. 2016. Public Spheres and Mediated Social Networks in the Western Context and Beyond. London: Palgrave Macmillan.

Keane, John. 2009. The Life and Death of Democracy. New York: Simon and Schuster.

Lai Stirland, Sarah. 2008. "Obama's Secret Weapons: Internet, Databases and Psychology." Wired Magazine, October 29. Accessed November 20, 2013. http://www.wired.com/threatlevel/ 2008/10/obamas-secret-w.

Weber, Max. (1946) 1998. "The Sociology of Charismatic Authority." In From Max Weber: Essays in Sociology, edited by H. Gerth and C. W. Mills. New York: Oxford University Press.

Petros losifidis (corresponding author) is Professor in Media Policy at City, University of London. He is author of several books including Global Media and Communication Policy (2013) and Global Media and National Policies (2016, with Terry Flew and Jeannette Steemers) and has published extensively in refereed journals. He is Editor of the International Journal of Digital Television and Co-Editor of the Book Series Palgrave Global Media Policy and Business, and he acts as Vice-Chair of IAMCR Global Media Policy working group, and adviser to the Greek government on media issues. E-mail: P.losifidis@city.ac.uk

Mark Wheeler is Professor of Political Communications at London Metropolitan University. He is the author of several books including Celebrity Politics: Image and Identity in Contemporary Political Communications (2013) and Public Spheres and Mediated Social Networks in the Western Context and Beyond (2016, with Petros losifidis). He has published a range of articles in peer-reviewed journals and chapters in edited books. He is a Visiting Fellow at the Media and Communications Department at the London School of Economics. E-mail: m.wheeler@londonmet.ac.uk 